\title{
Construction of a YAC Contig Covering Human Chromosome 6p22
}

\author{
Patrizia Malaspina, Antonella Roetto,* Flavia Trettel, Carla Jodice, Paola Blasi, \\ Marina Frontali, $†$ Massimo Carella, $\ddagger$ Brunella Franco, $\S$ \\ Clara Camaschella, ${ }^{*}$, and Andrea Novelletto $^{1}$
}

\begin{abstract}
Dipartimento di Biologia, Università di Roma Tor Vergata, 00133 Rome, Italy; *Dipartimento di Scienze Biomediche ed Oncologia Umana, Ospedale San Luigi, Orbassano, 10100 Turin, Italy; †Istituto di M edicina Sperimentale, C.N.R., 00137 Rome, Italy; ‡IRCCS-Ospedale CSS, 71013 San Giovanni Rotondo, Italy; §TIGEM, San Raffaele Biomedical Science Park, 20132 Milan, Italy; and "C.I.O.S., C.N.R., 10100 Turin, Italy
\end{abstract}

Received March 21, 1996; accepted June 19, 1996

\begin{abstract}
A contig covering human chromosome 6p22 that consists of 134 YAC clones aligned based on the presence/ absence of 52 DNA markers is presented. This contig overlaps with the 6p23 contig at its telomeric end and with the $6 \mathrm{p} 21.3$ contig at its centromeric end. The order of loci within the contig resolves the relative positions of several genetically mapped markers. Among the additional markers used here, there are eight novel PCR assays. The 12 known genes and anonymous ESTs located within the contig establish a first step toward a transcriptional map of this region. The instability of YAC clones observed during this work is also discussed. $\odot 1996$ Academic Press, Inc.
\end{abstract}

\section{INTRODUCTION}

The cytogenetic band $6 \mathrm{p} 22$ is a Giemsa positive band (GTG ${ }^{+}$; Holmquist, 1992) spanning approximately from genetic positions 34 to 46 , or $5-6 \%$ of the entire genetic length of chromosome 6 (Gyapay et al., 1994). Cytogenetically it has been measured to span $21 \%$ of the length of the chromosome 6 short arm (F rancke, 1994). This band is delimited centromerically by $6 \mathrm{p} 21$, a very gene-rich region containing the $\mathrm{MHC}$, and telomerically by $6 \mathrm{p} 23$. Both regions have been subjected to extensive physical analysis (Campbell et al., 1993; Nemani et al., 1994; Olavesen et al., 1995; Burt et al., 1996; Totaro et al., 1996). The intensive effort to generate new genetic markers (Gyapay, 1994) has identified several polymorphic and nonpolymorphic microsatellites that have been later anchored to $6 \mathrm{p} 22$ by FISH. However, in the first-generation physical map of the human genome (Cohen et al., 1993) this band was poorly covered, and in the recent report by Chumakov

P.M. and A.R. contributed equally to this study and should be regarded as joint first authors. B.F., C.C., and A.N. are senior authors.

${ }^{1}$ To whom correspondence should be addressed at Dipartimento di Biologia, Università di Roma Tor Vergata, Via della Ricerca Scientifica, 00133 Rome, Italy. Telephone: +39-6-72594321. Fax: +39-62023500. E-mail: terrenato@tovvx1.ccd.utovrm.it. et al. (1995) it is still represented by two separate paths of levels 3 and 1, respectively. In the STS-based map of the human genome (Hudson et al., 1995) two "doubly linked" contigs overlap this region.

Several genes have been assigned to 6p22. By using panels of somatic cell hybrids, Albig et al. (1993) assigned to this band the cluster of $\mathrm{H} 1$ histone genes; Abbott and Povey (1991) assigned the prolactin gene; Durkin et al. (1994) assigned brain-specific ESTs by PCR; and Pappas et al . (1995) found six ESTs mapping to 6p21.3-p23, one of which was identified as a zinc finger protein. A number of disease causing genes or cDNAs linked to the MHC are reported in OMIM with a possible location overlapping 6p22. These include the methionine-tRNA-i gene 1 (TRMI1), the transcription factor ID4, the COL 11A2 gene involved in Stickler syndrome and otospondylomegaephyseal dysplasia, the branched-chain alpha-keto acid dehydrogenase E1beta gene (BCKDHB), and one of the processed pseudogenes of the dihydrofolate reductase (DHFRP2). The location for the Sry-related gene SOX4 (Farr et al., 1993) has been shown to overlap $6 p 22$ by somatic cell hybrid analysis. Recently, the gene for hereditary idiopathic hemochromatosis (HFE) has been shown to be closely linked to markers in 6p22 (Raha-Chowdhury et al., 1995). Moreover, evidence from studies in independent family sets has accumulated (reviewed by Peltonen, 1995) in favor of a major locus predisposing to schizophrenia in a region overlapping 6p22. Finally, Foulkes et al. (1993), based on the finding of loss of heterozygosity, suggested the presence of a tumor suppresor gene relevant to ovarian carcinoma whose putative position may overlap 6p22.

To provide complete physical coverage of $6 \mathrm{p} 22$, we constructed a single YAC contig spanning from D6S306 centromerically to D6S109 telomerically, juxtaposing with the contiguous resource of YACs extended up to $6 p 24$ (Olavesen et al., 1995). In this work, the content of the same set of YAC clones was checked for an integrated assemblage of polymorphic genetic markers, anonymous STSs and ESTs, known genes, and anony- 
mous subcloned PCR products. Both PCR screening and hybridization probes were used to determine the relationship between the YAC clones.

\section{MATERIALS AND METHODS}

Isolation and preparation of YAC DNA. YAC clones from the CEPH (Albertsen et al., 1990; Chumakov et al., 1995) and ICI (Anand et al., 1991) libraries were obtained from the CEPH (Paris), ICRF (London), and DIBIT-HSR (Milan) resource centers. The original cultures and cultures obtained from single colonies were grown in AHC medium and resuspended in $80 \mu$ L LMP agarose plugs containing 7 $\times 10^{7}$ cells. Plugs were treated according to standard techniques. Two microliters of molten plug was used in PCR assays, whereas an entire plug was used for restriction enzyme digestion, agarose electrophoresis, and Southern transfer. Probe labeling and hybridization were performed according to standard techniques. Filter washing was performed at high stringency.

Devel opment of new markers. We generated new STSs and probes by using three different methods: (1) Alu-PCR products were generated from selected YACS. PCR with $250 \mathrm{ng}$ of one of the primers described by Nelson et al. (1989) was carried out for 35 cycles with $1.5 \mathrm{mM} \mathrm{MgCl} 2$ and an annealing temperature of $65^{\circ} \mathrm{C}$. After agarose electrophoresis, bands distinctive for recombinant yeast were eluted and reamplified under the same conditions to reduce contamination by nonspecific products. Some of these bands were subcloned (BTVC1.5, BTVD1.4, BTVG2.9), while others were eluted from $1 \%$ LMP agarose gels and used as hybridization probes to filters containing either Alu-PCR products or digested DNA of individual YACS in the region. Hybridization was carried out as described by Wapenaar et al. (1994) in the presence of total human DNA to suppress signals from repetitive sequences (Sealey et al., 1985). (2) PCR products were generated with a pool of primers designed on splicing donor and acceptor site consensus sequences (Pritchard et al., 1994; Senapathy et al., 1990) (BTV9F, SSADH). PCR was performed with 25 pmol each of 3 primers with $1.5 \mathrm{mM} \mathrm{MgCl}_{2}$ for 35 cycles with an annealing temperature of $45^{\circ} \mathrm{C}$. After agarose el ectrophoresis, bands not observed in wildtype yeast were eluted and reamplified under the same conditions. (3) The third method relied on the observation that nonspecific PCR products were generated by some markers on certain sets of YACs. In some cases the presence/absence pattern of such bands was consistent with a location of the corresponding target sequences within the contig. The bands were then excised, subcloned, and sequenced, and specific primers were developed (BTVOL506).

Products obtained with the above methods were subcloned in pUC18 as blunt-ended inserts (Sure Clone kit, Pharmacia) and sequenced with universal primers with the dideoxy chain termination method by Taq polymerase (AmpliCycle kit, Perkin-EImer). The sequences were then checked for their repetitive content by comparison with human repetitive elements (J urka et al., 1992). Primers were designed to obtain PCR products in the 100- to 500-bp range from the nonrepetitive regions. The genomic origin of the STSs was checked on a somatic cell hybrid retaining the sole human chromosome 6 on hamster background (GM 10629A; NI GMS Human Genetic Mutant Cell Repository).

A specific assay for human butyrophilin (BT) was developed: the PCR product obtained using bovine primers (Amadou et al., 1995) on human genomic DNA was directly sequenced to design humanspecific primers. PCR conditions of the above-mentioned markers are reported in Table 1.

Alu-vector probes were generated from individual YACs by using Alu and vector primers as previously described (Nelson et al., 1989; Zoghbi and Chinault, 1995). The bands were eluted from agarose gels and used as hybridization probes to digested DNA of individual YACs using the protocol for suppression of signals from repetitive sequences (Sealey et al., 1985).

Probes, PCR primers, and conditions. All STS markers used the buffer recommended by the manufacturer (Promega), $0.2 \mathrm{mM}$ dNTPs, $10 \mathrm{pmol}$ of each primer, $2 \mu \mathrm{l}$ of molten yeast plug as template in a final volume of $20 \mu \mathrm{l}$, and the same PCR thermal profile with the exception of the annealing conditions and number of cycles. The standard conditions were $4 \mathrm{~min}$ at $94^{\circ} \mathrm{C}$, then the appropriate number of cycles of $45 \mathrm{~s}$ at $94^{\circ} \mathrm{C}$, annealing, and $45 \mathrm{~s}$ at $72^{\circ} \mathrm{C}$, followed by a final extension of $5 \mathrm{~min}$ at $72^{\circ} \mathrm{C}$. I $\mathrm{n}$ all experiments, distilled water and yeast strain AB1380 DNA were used as negative controls, and genomic DNA was used as a positive control. The markers taken from the literature and the corresponding PCR annealing and cycling conditions are listed in Table 2.

\section{RESULTS}

\section{Initial Assembly of Contigs}

An initial set of 154 YACs identified from the first release of Généthon data (Cohen et al., 1993) to reside potentially in $6 \mathrm{p} 22$ was assembled. Clonal cultures were grown and DNA prepared to retest YACs individually with the markers used to construct the genetic map, D6S422, D6S299, D6S461, D6S464, D6S306, D6S258, D6S276, D6S265, and D6S273. Among the YACs detected by tridimensional screening at Généthon to contain these microsatellite markers, 24\% were not confirmed by individual testing. On the other hand, we found 33 YACs positive with at least one of these markers and not reported as positive in Généthon files. We then added individual analyses for markers D6S109, SOX4, D6S506, D6S507, D6S242, D6S105, H1.5, and TRMI 1 .

The 76 YACs positive for at least one of the markers listed above could be arranged in four separate contigs: the first one contained D6S109, D6S422, SOX4, D6S507, and D6S506; the second one contained D6S276, D6S461, D6S299, and D6S242; the third one contained D6S464, D6S306, H1.5, and D6S105; and the fourth one contained D6S273, D6S258, and D6S265. These results showed that the STS content of the YACS could provide a finer resolution than the genetic map. In fact, Chumakov et al. (1995) reported that the loci D6S464, D6S306, D6S258, D6S276, and D6S265 represent the single position 0.46 together with the HLA cluster. On the other hand, our analysis grouped D6S276 in a cluster mapped $4 \mathrm{cM}$ telomerically and placed D6S258 and D6S265 in the proximity of D6S273. When our pool of YACs was assayed by hybridization with a probe specific for the tel omeric MHC gene HLA-F (Amadou et al., 1995), only YACs of the fourth contig produced a positive signal. This placed the latter subgroup of YACs centromeric to the others. This region was not considered for further analysis.

\section{Filling Gaps}

To fill the gaps between the contigs and to extend the coverage to the 6 p22-p23 boundary (Olavesen et al., 1995), we used different methods to generate additional STS markers in the form of PCR assays. This search was directed toward single-copy loci to avoid the problems associated with contig assembly in the presence of repeated or highly homologous loci (F oote et al., 1992). Two methods were used to select low-copy 
TABLE 1

New Markers Developed

\begin{tabular}{|c|c|c|c|c|c|}
\hline $\begin{array}{c}\text { Name } \\
\text { (original YAC) }\end{array}$ & Size (bp) & Primers & $\begin{array}{l}\text { Annealing } \\
\text { conditions }\end{array}$ & $\mathrm{MgCl}_{2}(\mathrm{mM})$ & Cycles \\
\hline $\begin{array}{l}\text { BTVC1.5 } \\
\text { (738_b_5) }\end{array}$ & 105 & $\begin{array}{l}\text { CAGATGCTATGCTTCAC } \\
\text { CCAACAGATGGGTTTAG }\end{array}$ & $52^{\circ} \mathrm{C}, 30 \mathrm{~s}$ & 1.5 & 30 \\
\hline $\begin{array}{l}\text { BTVG2.9 } \\
\text { (927_e_10) }\end{array}$ & 160 & $\begin{array}{l}\text { ACTCAGTATAATTCCATAG } \\
\text { AACTGTATTGCTTGTACAC }\end{array}$ & $52^{\circ} \mathrm{C}, 30 \mathrm{~s}$ & 1.5 & 30 \\
\hline $\begin{array}{l}\text { BTVDI.4 } \\
\text { (934_d_11) }\end{array}$ & 450 & $\begin{array}{l}\text { CTTTAATTCAAGAAGAGAAC } \\
\text { GTGAAGCATAGGTGATTG }\end{array}$ & $49^{\circ} \mathrm{C}, 30 \mathrm{~s}$ & 1.5 & 30 \\
\hline $\begin{array}{l}\text { BTV9F } \\
\text { (830_b_5) }\end{array}$ & 264 & $\begin{array}{l}\text { CCTGATTTAAAGCACATGGC } \\
\text { GCATTTACTGTCTTCTTGCC }\end{array}$ & $53^{\circ} \mathrm{C}, 30 \mathrm{~s}$ & 1.5 & 35 \\
\hline BTVOL506 & 230 & $\begin{array}{l}\text { CCAACATGCAGACACACTAC } \\
\text { GACTATAAGGGGGAAAGGC }\end{array}$ & $55^{\circ} \mathrm{C}, 30 \mathrm{~s}$ & 1.5 & 35 \\
\hline $\begin{array}{l}\text { SSADH } \\
\text { (775_g_10) }\end{array}$ & 203 & $\begin{array}{l}\text { GTGTCTTCGGCAGGCTTC } \\
\text { GGTTTGTCAATCAGTTGTGC }\end{array}$ & $55^{\circ} \mathrm{C}, 30 \mathrm{~s}$ & 1.5 & 35 \\
\hline L 34820 & 94 & $\begin{array}{l}\text { TATGTGTGTTACGGGGGC } \\
\text { AATAATGGATGGCATGTACC }\end{array}$ & $54^{\circ} \mathrm{C}, 30 \mathrm{~s}$ & 1.5 & 35 \\
\hline BT & 198 & $\begin{array}{l}\text { CAGAGAGATTTGACTCCTGG } \\
\text { CAGTACCCATTTCCATACAAC }\end{array}$ & $65^{\circ} \mathrm{C}, 45 \mathrm{~s}$ & 2.5 & 30 \\
\hline
\end{tabular}

YAC fragments: preliminary amplification of inter-Alu DNA or amplification with a pool of primers potentially specific for coding sequences (see Materials and Methods). Of 67 bands identified in YAC-bearing but not wildtype yeast, 29 (43\%) were successfully picked and reamplified in a second PCR run under the same conditions. The 16 products cloned and fully sequenced were compared with a compilation of human repetitive elements with FASTA. Six of them still contained repetitive sequences that prevented a specific assay, 1 was an artifact resulting from primer multimerization during the repeated amplifications, and 9 did not show any relevant homology with repetitive elements (optimal alignment scores 49-99) and were considered for PCR development. The check for repetitive content by computer analysis alone turned out to be highly effective. When PCR was performed under stringent conditions (Table 1), in 9 of 9 cases a sharp band of the expected molecular weight was obtained. When tested as probes against digested human genomic DNA, all of these products hybridized to a single band, as expected for single-copy sequences. By performing specific PCR assays on a hamster hybrid containing only human chromosome 6 , four of nine STSs were excluded from this chromosome, thus confirming that material from chromosomes other than chromosome 6 is abundant in the YACs used. By comparison with sequences in GenBank, one of the clones contained a 244-bp insert that shared a stretch of identity with the human SSADH gene (Chambliss et al., 1995). We then designed an additional PCR assay (L34820) to amplify the 3 '-end of coding and part of the 3'-untranslated regions of human SSADH CDNA specifically.

We observed a nonspecific PCR product generated by marker D6S506 on genomic DNA. A group of adjacent YACs replicated this spurious band, suggesting the presence of a second locus homologous to D6S506 in $6 p 22$. Subcloning and sequencing of this band led to another STS (BTVOL506, Table 1).
The description of the butyrophilin locus (Amadou et al., 1995; Vernet et al., 1993) in a region of the mouse genome showing homology with the human 6p22 led us to devel op a specific PCR assay for the human BT.

These novel markers were used to rescreen the Mega$\mathrm{CEPH}$ and $\mathrm{ICl}$ libraries. Additional YACs were also included in our analysis based on the results of screening reported by the MIT Genome Center with CHLC and newly developed STSs (10 markers).

The set of YACs, now totaling 243, was analyzed with all of the above-mentioned markers as well as a series of ESTs and known genes mapped or possibly mapping to $6 \mathrm{p} 22$. One hundred thirty-four YAC clones turned out to contain at least one marker and could be now arranged in a single contig reaching at its telomeric end a region already covered in 6p23 (Olavesen et al., 1995).

Figure 1 shows a simplified version of the contig comprising 65 YACs. The remaining YACs were omitted for simplicity of presentation but the overall number of Y ACs positive for each marker is reported. A variable redundancy is apparent, but it is not possible to determine whether this is the result of an unequal representation in the original libraries or is due to a still incomplete detection during the screening procedure.

The order of markers was established by the presence of two or more markers within a single YAC (Fig. 1, last row) and by building up the number of overlapping clones. In addition, inter-Alu band probes were used as hybridization probes to reinforce the link between adjacent loci further.

\section{Resolving Ambiguities}

The order of markers presented in Fig. 1 generated the minimum number of internal deletions irrespective of the number of markers missing in each case. The relative positions of D6S242 vs D6S461 and AFM342xe5 vs SOX4 could not be resolved because the two markers in each of these pairs showed a perfect 
TABLE 2

Previously Described Markers Used in 6p22 Physical Mapping

\begin{tabular}{|c|c|c|c|c|}
\hline \multirow[b]{2}{*}{ Name } & \multicolumn{3}{|c|}{ PCR conditions } & \multirow[b]{2}{*}{ References } \\
\hline & Annealing & $\mathrm{MgCl}_{2}(\mathrm{mM})$ & Cycles & \\
\hline Histone gene $\mathrm{H} 1.1$ & $50^{\circ} \mathrm{C}, 60 \mathrm{~s}$ & 1.5 & 30 & Albig et al., 1993 \\
\hline Histone gene $\mathrm{H} 1.2$ & $56^{\circ} \mathrm{C}, 45 \mathrm{~s}$ & 1.5 & 30 & Albig et al., 1993 \\
\hline Histone gene $\mathrm{H} 1.3$ & $63^{\circ} \mathrm{C}, 30 \mathrm{~s}$ & 1.5 & 30 & Albig et al., 1993 \\
\hline Histone gene $\mathrm{H} 1.4$ & $63^{\circ} \mathrm{C}, 30 \mathrm{~s}$ & 1.5 & 30 & Albig et al., 1993 \\
\hline Histone gene $\mathrm{H} 1.5$ & $58^{\circ} \mathrm{C}, 45 \mathrm{~s}$ & 1.5 & 35 & Albig et al., 1993 \\
\hline D6S422 & $52^{\circ} \mathrm{C}, 45 \mathrm{~s}$ & 1.5 & 35 & Gyapay et al., 1994 \\
\hline AFM342xe5 & $47^{\circ} \mathrm{C}, 45 \mathrm{~s}$ & 1.5 & 30 & Gyapay et al., 1994 \\
\hline AF M 082tel & $59^{\circ} \mathrm{C}, 45 \mathrm{~s}$ & 1.5 & 30 & Gyapay et al., 1994 \\
\hline D6S461 & $55^{\circ} \mathrm{C}, 30 \mathrm{~s}$ & 1.5 & 35 & Gyapay et al., 1994 \\
\hline D6S299 & $52^{\circ} \mathrm{C}, 45 \mathrm{~s}$ & 1.5 & 35 & Gyapay et al., 1994 \\
\hline D6S276 & $55^{\circ} \mathrm{C}, 45 \mathrm{~s}$ & 1.5 & 30 & Gyapay et al., 1994 \\
\hline D6S464 & $52^{\circ} \mathrm{C}, 45 \mathrm{~s}$ & 1.5 & 35 & Gyapay et al., 1994 \\
\hline D6S265 & $55^{\circ} \mathrm{C}, 30 \mathrm{~s}$ & 1.5 & 35 & Gyapay et al., 1994 \\
\hline D6S258 & $55^{\circ} \mathrm{C}, 30 \mathrm{~s}$ & 1.5 & 35 & Gyapay et al., 1994 \\
\hline D6S273 & $53^{\circ} \mathrm{C}, 45 \mathrm{~s}$ & 1.5 & 30 & Gyapay et al., 1994 \\
\hline D6S306 & $52^{\circ} \mathrm{C}, 45 \mathrm{~s}$ & 1.5 & 35 & Gyapay et al., 1994 \\
\hline EST449 & $52^{\circ} \mathrm{C}, 45 \mathrm{~s}$ & 1.5 & 35 & Pappas et al., 1995 \\
\hline EST2534 & $57^{\circ} \mathrm{C}, 30 \mathrm{~s}$ & 1.5 & 30 & Pappas et al., 1995 \\
\hline EST798 & $54^{\circ} \mathrm{C}, 30 \mathrm{~s}$ & 1.5 & 35 & Pappas et al., 1995 \\
\hline SOX4 & $65^{\circ} \mathrm{C}, 30 \mathrm{~s}$ & 1.5 & 35 & Farr et al., 1993 \\
\hline WI9755 & $58^{\circ} \mathrm{C}, 45 \mathrm{~s}$ & 1.5 & 35 & Hudson et al., 1995 \\
\hline D6S1078 & $62^{\circ} \mathrm{C}, 45 \mathrm{~s}$ & 1.5 & 30 & Hudson et al., 1995 \\
\hline D6S1074 & $60^{\circ} \mathrm{C}, 60 \mathrm{~s}$ & 1.5 & 30 & Hudson et al., 1995 \\
\hline WI 7513 & $62^{\circ} \mathrm{C}, 45 \mathrm{~s}$ & 1.5 & 30 & Hudson et al., 1995 \\
\hline D6S1328 & $52^{\circ} \mathrm{C}, 45 \mathrm{~s}$ & 1.5 & 30 & Hudson et al., 1995 \\
\hline WI3998 & $56^{\circ} \mathrm{C}, 45 \mathrm{~s}$ & 1.5 & 30 & Hudson et al., 1995 \\
\hline D6S1921 & $52^{\circ} \mathrm{C}, 45 \mathrm{~s}$ & 1.5 & 30 & Hudson et al., 1995 \\
\hline D6S1468 & $56^{\circ} \mathrm{C}, 45 \mathrm{~s}$ & 1.5 & 30 & Hudson et al., 1995 \\
\hline D6S1918 & $58^{\circ} \mathrm{C}, 90 \mathrm{~s}$ & 1.5 & 30 & Hudson et al., 1995 \\
\hline D6S1422 & $58^{\circ} \mathrm{C}, 45 \mathrm{~s}$ & 1.5 & 30 & Hudson et al., 1995 \\
\hline 1255 & $52^{\circ} \mathrm{C}, 45 \mathrm{~s}$ & 1.5 & 30 & Hudson et al., 1995 \\
\hline 1501 & $52^{\circ} \mathrm{C}, 45 \mathrm{~s}$ & 1.5 & 30 & Hudson et al., 1995 \\
\hline 1001 & $58^{\circ} \mathrm{C}, 30 \mathrm{~s}$ & 1.5 & 30 & Hudson et al., 1995 \\
\hline GATAP19326 & $56^{\circ} \mathrm{C}, 45 \mathrm{~s}$ & 1.5 & 30 & Hudson et al., 1995 \\
\hline STS_G9945 & $58^{\circ} \mathrm{C}, 90 \mathrm{~s}$ & 2.5 & 30 & Hudson et al., 1995 \\
\hline D6S1558 & $65^{\circ} \mathrm{C}, 45 \mathrm{~s}$ & 1.5 & 30 & Hudson et al., 1995 \\
\hline D6S1016 & $60^{\circ} \mathrm{C}, 45 \mathrm{~s}$ & 1.5 & 30 & Buetow et al., 1994 \\
\hline D6S1050 & $60^{\circ} \mathrm{C}, 45 \mathrm{~s}$ & 1.5 & 30 & Buetow et al., 1994 \\
\hline D6S1002 & $60^{\circ} \mathrm{C}, 60 \mathrm{~s}$ & 1.5 & 30 & Stone et al., 1994 \\
\hline D6S109 & $65^{\circ} \mathrm{C}, 30 \mathrm{~s}$ & 1.5 & 35 & Ranum et al., 1991 \\
\hline D6S506 & $60^{\circ} \mathrm{C}, 60 \mathrm{~s}$ & 1.5 & 30 & GDB \\
\hline D6S507 & $67^{\circ} \mathrm{C}, 60 \mathrm{~s}$ & 1.5 & 30 & GDB \\
\hline D6S986 & $67^{\circ} \mathrm{C}, 120 \mathrm{~s}$ & 1.5 & 30 & GDB \\
\hline D6S242 & $58^{\circ} \mathrm{C}, 45 \mathrm{~s}$ & 1.5 & 35 & GDB \\
\hline PRL & $66^{\circ} \mathrm{C}, 60 \mathrm{~s}$ & 1.5 & 30 & Abbott and Povey, 1991 \\
\hline TRMII & $50^{\circ} \mathrm{C}, 60 \mathrm{~s}$ & 1.5 & 30 & Polymeropoulos et al., 1991 \\
\hline PGC & $55^{\circ} \mathrm{C}, 45 \mathrm{~s}$ & 1.5 & 30 & Hayano et al., 1988 \\
\hline DSP & $57^{\circ} \mathrm{C}, 45 \mathrm{~s}$ & 1.5 & 30 & Arnemann et al., 1991 \\
\hline DHFRP2 & $55^{\circ} \mathrm{C}, 45 \mathrm{~s}$ & 1.5 & 30 & Anagnou et al., 1985 \\
\hline D6S346E & $62^{\circ} \mathrm{C}, 60 \mathrm{~s}$ & 1.5 & 30 & Durkin et al., 1994 \\
\hline D6S105 & $54^{\circ} \mathrm{C}, 60 \mathrm{~s}$ & 1.5 & 30 & Weber et al., 1992 \\
\hline 729LK & $65^{\circ} \mathrm{C}, 30 \mathrm{~s}$ & 2.5 & 28 & H. Zoghbi, pers. comm., 1994, Houston, TX \\
\hline
\end{tabular}

correlation for their presence/absence in YACs (Fig. 1, last two rows). This was also true for SSADH vs L34820. However, we were ableto determine their relative order by hybridizing the flanking YACs with a cDNA probe overlapping the 3 '-end of the gene. This result further confirmed the assignment of the SSADH gene to this chromosomal region.
On the other hand, YAC deletions in the $\mathrm{H} 1$ histone cluster generated ambiguities to order the corresponding markers. Among several best-fitting orders, Fig. 1 shows that obtained by Volz et al. (1994) on the basis of long-range restriction mapping.

The entire set of markers is "doubly linked" to adjacent markers within the contig with three exceptions 


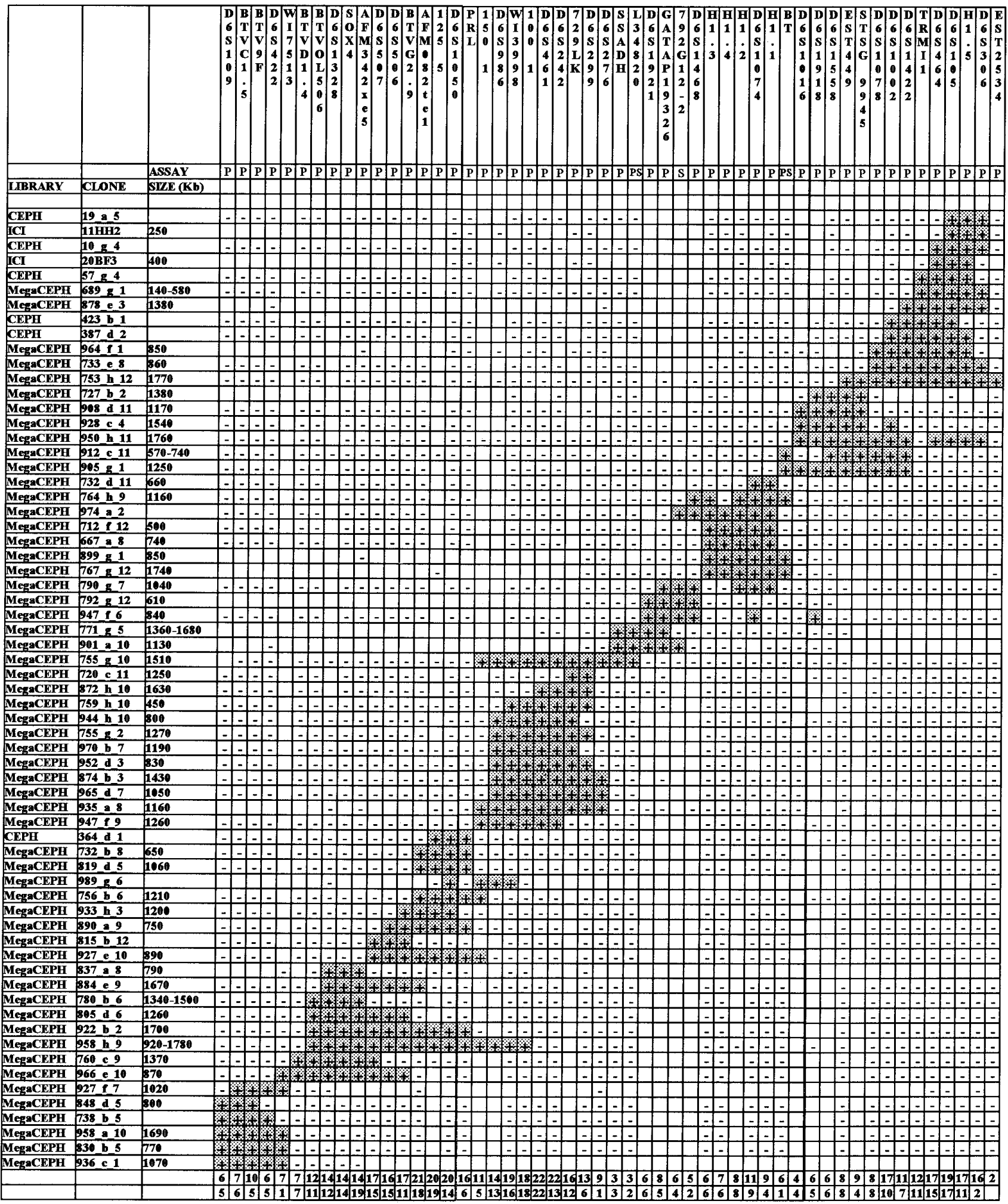

FIG. 1. Results of YAC alignment based on marker content of clones. A subset of 65 YACs is shown. Presence (+) or absence (-) of DNA markers in YAC clones is indicated. The second row reports the method of marker ascertainment: P, PCR; S, Southern blotting. The penultimate row reports the overall number of YACs containing the corresponding marker. The last row reports the number of YACs containing simultaneously each marker and the marker immediately to its right. 
(Fig. 1, last row). The first "singly linked" interval is between markers WI7513 and BTVD1.4, which are both contained only in YAC 966_e 10; the second is between D6S276 and SSADH (755_g_10), and the third is between BT and D6S1016 (905_g_1).

An estimate of the size of the YAC contig can be made by summing the sizes of the smallest overlapping and nonoverlapping YACs with no known deletion across the contig. By these means the region covered is $8.0-9.0 \mathrm{Mb}$.

The order of markers in the contig refines the relative positions of loci reported in the CEPH genetic map (Chumakov et al., 1995). In particular, D6S285 and D6S422 (3 cM) are separated by 9 markers, as determined by our results and those by Olavesen et al. (1995); D6S422 and D6S461 (5 cM) are separated by 17 markers. D6S461 and D6S299, not genetically resolved, are now oriented based on the discordant results of YACs 720 c 11, 944 h_10, 970 b 7, and 947 f 9 (Fig. 1). In ağreement with the MIT data (contig W' 140$),$ D6S276, genetically mapped 4 cM from [D6S461-D6S299], turns out to be adjacent to D6S299, with its position being defined by discordant results in several YACs. D6S299 and D6S464 (4 cM) are separated by 22 markers and 2 additional markers separate the latter from D6S306. Our contig also supports the consensus map reported by Volz et al. (1994) with odds of only 14:1. YAC 423_b_1 places D6S105 telomerically although very close to $\bar{H} 1.5$. The finding that the $H L A-$ $F$ probe does not hybridize with YACs containing D6S464, D6S306, and D6S276 is in agreement with the location of HLA further centromeric to the $\mathrm{H} 1$ histone cluster and, by extension, to the above-mentioned loci (Amadou et al., 1995; Volz et al., 1994). This is in line with the observation that among the 42 YACs reported by Chumakov et al. (1995) to contain genetic position 0.46 , not one scored simultaneously positive for any of the three microsatellite markers and the MHC cluster markers. The order of markers here reported confirms that of the doubly linked MIT contig WC140 and establishes a link between WC140 and WC1316. In the integrated map (Hudson et al., 1995), however, D6S1422 is placed telomerically to D6S1918, and AFM $342 x e 5$ is placed telomerically to D6S1328, an order not supported in our contig. In addition, the same authors report AFM342xe5 and WI 7513 to comap in the same radiation hybrid, whereas we resolve their order with four intervening markers.

Inter-Alu bands and anonymous probes from the insert-vector boundary of selected YACs were generated to reinforce the link between adjacent loci further. 792 G12 2 is a specific Alu band obtained by AluPCR of YAC 792_g_12 (Fig. 1). LE952D3, LE 912C11, and LE20BF3, obtained by the corresponding YAC clones by using Alu-vector protocols, when used as hybridization probes on a subset of YACs demonstrated that the corresponding inserts are oriented as reported in Table 3.

\section{Instability of YACs}

Thirty cultures of the Mega-YAC library were examined in double or triple replicates by two laboratories that obtained them through different resource centers, i.e., after several rounds of mitotic propagation. Of the YACs in this group, 15 gave identical positive results for both members of each pair, 1 gave identical negative results, while 5, 4, 2, and 3 exhibited a loss of one, two, three or four markers, respectively ( $47 \%$ of YACs with losses). The finding of such a high rate of marker loss raises questions as to whether it may affect the ordering of loci. F orty-one markers were examined in at least a pair of subcultures of the same original YAC clone, and 155 markers $\times$ pair assays were performed. Overall 31 markers showed loss in one culture among the examined pairs (10\% rate of loss). Thus there is a $90 \%$ chance for a given marker to be retained in a YAC, ensuring that, with the number of clones examined in this work and found positive (Fig. 1, last two rows), the order of loci can be reliably inferred. Indeed, visual inspection of the contig showed that the ordering of loci involved in losses in each pair is supported by several other YAC clones. An exception is represented by the $\mathrm{H} 1$ cluster-containing region, where the order of loci was drawn from long-range restriction mapping (Volz et al., 1994). Recurrent marker loss and the low efficiency in obtaining Y ACs from this region (Fig. 1, penultimate row) might be the result of enhanced mitotic instability of YACs containing portions of this region of the genome.

\section{DISCUSSION}

We have constructed an integrated map of chromosome $6 p 22$ consisting of YACs, polymorphic genetic markers, anonymous STS and ESTs, anonymous subcloned Alu-PCR products, and known genes. We primarily used PCR screening to determine the relationships between the YAC clones, but hybridization probing was also used to confirm them. We developed novel STS markers and integrated their analysis with previously described markers in the characterization of the same set of YAC clones.

We resolved the relative positions of nine markers used to construct the Généthon genetic map (Gyapay et al., 1994), confirmed the presence of six of them in this region, and assigned the remaining three to the more proximal MHC-containing region. In fact, in their recent report, Burt et al. (1996) physically mapped D6S265 and D6S258 in the proximity of HLA-A and HLA-F genes. D6S276, one of the markers used in the recent radiation hybrid framework map (Gyapay et al., 1996), is retained in many of the YACs harboring D6S299 and in none of those harboring either D6S464 or D6S306. Its position is thus considered more telomeric than previously reported, perhaps as a result of a limited number of recombination events with respect to neighboring markers. The repositioning of 
TABLE 3

Hybridization Probes

\begin{tabular}{clll}
\hline Name (original YAC) & Probe type & Position & \multicolumn{1}{c}{ Positive clones } \\
\hline LE952D3 & $\begin{array}{l}\text { Alu-vector } \\
\text { (left end) }\end{array}$ & Telomeric end & 874_b_3, 965_d_7, 970_b_7, 935_a_8, 947_f_9 \\
LE912_C11 & $\begin{array}{l}\text { Alu-vector } \\
\text { (left end) }\end{array}$ & Centromeric end & 753_h_12, 964_f_1 \\
(912_C_11) & $\begin{array}{l}\text { Alu-vector } \\
\text { (left end) }\end{array}$ & Centromeric end & 753_h_12, 11HH2 \\
LE2OBF3 & (2OBF3) & & \\
\hline
\end{tabular}

D6S276 would imply the breakdown of the level 1 path between genetic positions 0.42 and 0.46 (Chumakov et al., 1995).

We superimposed on this map 46 additional markers. These include the SOX4, prolactin, butyrophilin, and methionine-t-RNA genes as well as the $\mathrm{H} 1$ histone cluster containing several genes (Albig et al., 1993). We could physically locate this cluster for the first time between D6S1468 and D6S1016. In addition, we refined the location of two of six ESTs with a 6p22-p23 assignment (Pappas et al., 1995) by positioning them within the contig. We assigned for the first time the gene for $\mathrm{NAD}^{+}$-dependent succinic semialdehyde dehydrogenase (SSADH) to this portion of the genome and found it to be oriented from telomere to centromere.

The number of markers per genetic interval correlates fairly well with the genetic distances reported by Chumakov et al. (1995), providing no evidence for a biased distribution. By virtue of the new markers we were able to bring all paths between adjacent loci to level 1.

When comparing our results with those of the MIT Genome Center, the STS WI 9755 was not found in any of our YACs. In particular, we examined individually YACs 787 d 1, 847 c 8, 927 f 10, and 844 h_10, reported with three "definite" $Y \bar{A} \bar{C} / S T S$ hits and one "ambiguous" YAC/STS hit in the contig WC140. The first two were indeed confirmed to share markers at the telomeric end of $6 p 22$. With this exception, we observed a better agreement with the individual doubly linked contigs rather than the integrated map, since in some instances it reports an alternative order of markers. In this work we examined Y ACs individually, thus excluding the imprecision introduced by the tridimensional screening scheme (Hudson et al., 1995). Recurrent loss of markers in independent YACs or complex rearrangements in radiation hybrids may contribute to the observed discrepancies with the integrated map.

We excluded from this region the DHFRP2 and DSP genes and the EST D6S346E, reported in the literature with 6pter-qter, 6pter-p21, and 6p22.1-p21.3 assignments, respectively. Moreover, we excluded the EST798 (Pappas et al., 1995), an expressed sequence assigned to 6p22-p23. Olavesen et al. (1995) excluded its presence from 6 p23 as well, thus leaving the precise position of this sequence still to be determined.

The anchoring of our contig is established by the assignment of YACs 878 e 3 and 753 h_12 by FISH (Bray-Ward et al., 1996). These clones àre found on the proximal side of our contig (Fig. 1) and produced hybridization signals on proximal $6 \mathrm{p} 22$ and the 6p21.3-p22 boundary, respectively.

Centromerically, our contig reaches the contig reported by Burt et al. (1996), sharing with it four YACs and three markers, and ensuring that 6 p22 is physically covered up to its proximal end. In addition, we could orient and order several markers reported to lie in the proximity of the 6p21.3- p22 boundary (Amadou et al., 1995; Raha-Chowdhury et al., 1995; Vernet et al., 1993). Based on the volume of metaphase chromosome (Heslop-Harrison et al., 1989) and the relative length of bands (Franke, 1994), the 6p22 band can be estimated to span $13 \mathrm{Mb}$. However, this measurement is hardly comparable with the length of our contig, due to variations in the extent of chromosome condensation. To its telomeric end, our contig reaches that published by Olavesen et al. (1995), sharing with it five YACs and three markers. The continuous resource of aligned YAC clones now spans from $6 p 21.3$ to distal 6p24.3 (Davies et al., 1995).

Our work enabled us to evaluate the instability of YAC clones upon several runs of mitotic propagations and revealed a remarkable proportion of YACs with marker losses. This might considerably affect the usefulness of YACs in constructing contigs based on STS content. We used a large number of independent clones to increase internal consistency and found reproducible links between adjacent loci in most cases.

The expressed genes localized within the contig and the reagents utilized in this work provide the first core of a transcriptional map of this chromosomal region.

\section{ACKNO WLEDGMENTS}

We are grateful to Drs. J. Ragoussis, M. Olavesen, and H. Cann for their continuous support, sharing of data, and help in obtaining reagents and to Professor $L$. Terrenato for his invaluable advice. We are also indebted to Professor A. Ballabio for support and discussion. The collaboration of Drs. D. Toniolo and C. Sala for the screening of the $\mathrm{CEPH}$ and $\mathrm{ICl}$ libraries is gratefully acknowledged. We thank C. Grottoli for technical assistance. This work was supported by E.U. BIOMED Contracts GENE-CT93-0075, GENE-CT93-0101 (Eurogem), and BMH4-CT96-0994, MURST 60\%, and the I talian Telethon Foundation. 


\section{REFERENCES}

Abbott, C., and Povey, S. (1991). Development of human chromosome-specific PCR primers for characterization of somatic cell hybrids. Genomics 9: 73- 77.

Albertsen, H. M., Adberrahim, H., Cann, H. M., Dausset, J ., Le Paslier, D., and Cohen, D. (1990). Construction and characterization of a yeast artificial chromosome library containing seven haploid human genome equivalents. Proc. Natl. Acad. Sci. USA 87: 42564260.

Albig, W., Drabent, B., Kunz, J ., Kalff-Suske, M., Grzeschik, K., and Doenecke, D. (1993). All known human $\mathrm{H} 1$ histone genes except the $\mathrm{H}^{\circ}$ gene are clustered on chromosome 6. Genomics 16: 949654.

Amadou, C., Ribouchon, M. T., Mattei, M. G., J enkins, N. A., Gilbert, D. J ., Copeland, N. G., Avoustin, P., and Pontarotti, P. (1995). Localization of new genes and markers to the distal part of the human major histocompatibility complex (MHC) region and comparison with the mouse: New insights into the evolution of mammalian genomes. Genomics 26: 9- 20.

Anagnou, N. P., Antonarakis, S. E., O'Brien, S. J ., and Nienhuis, A. W. (1985). Chromosomal localization and racial distribution of the polymorphic hDHFR-psi-1 pseudogene. Clin. Res. 33: 328A.

Anand, R., Ogilvie, D. J ., Butler, R., Riley, J . H., Finniear, R. S., Powell, S. J., Smith, J. C., and Markham, A. F. (1991). A yeast artificial chromosome contig encompassing the cystic fibrosis locus. Genomics 9: 124- 130.

Arnemann, J ., Spurr, N. K., Wheeler, G. N., Parker, A. E., and Buxton, R. S. (1991). Chromosomal assignment of the human genes coding for the major proteins of the desmosome junction, Desmoglein DGI (DSG), desmocollins DGII/III (DSC), desmoplakins DPI/II (DSP), and plakoglobin DPIII (J UP). Genomics 10: 640645.

Bray-Ward, P., Menninger, J ., Liemann, J ., Desai, T., Mokady, N., Banks, A., and Ward, D. C. (1996). Integration of the cytogenetic, genetic, and physical maps of the human genome by FISH mapping of CEPH YAC clones. Genomics 32: 1- 14.

Buetow, K. H., Weber, J . L., Ludwigsen, S., Scherpbier-Heddema, T., Duyk, G. M., Sheffield, V. C., Wuang, Z., and Murray, J. C. (1994). Integrated human genome-wide maps constructed using the CEPH reference panel. Nature Genet. 6: 391- 394.

Burt, M. J ., Smit, D. J ., Pyper, W. R., Powell, L. W., and J azwinska, E. C. (1996). A 4.5-megabase YAC contig and physical map over the hemochromatosis gene region. Genomics 33: 153- 155.

Campbell, R. D., and Trowsdale, J . (1993). Map of the human MHC. Immunol. Today 14: 349-352.

Chambliss, K. L., Caudle, D. L., Hinson, D. D., Moomaw, C. R., Slaughter, C. A., J akobs, C., and Gibson, K. M. (1995). Molecular cloning of the mature $\mathrm{NAD}^{+}$-dependent succinic semialdehyde dehydrogenase from rat and human. J . Biol. Chem. 270: 461- 467.

Chumakov, I. M., Rigault, P., Le Gall, I., Bellannè-Chantelot, C., Billault, A., Guillou, S., Soularue, P., Guasconi, G., Poullier, E., Gros, I., Belova, M., Sambucy, J . L., Susini, L., Gervy, P., Glibert, F., Beaufils, S., Bui, H., Massart, C., De Tand, M. F., Dukasz, F., Lecoulant, S., Ougen, P., Perrot, V., Saumier, M., Soravito, C., Bahouayila, R., Cohen-Akenine, A., Barillot, E., Bertrand, S., Codani, J . J ., Caterina, D., Georges, I., Lacroix, B., Lucotte, G., Sahbatou, M., Schmit, G., Sangouard, M., Tubacher, E., Dib, C., Fauré, S., Fizames, C., Gyapay, G., Millasseau, P., NGuyen, S., Muselet, D., Vignal, A., Morissette, J ., Menninger, J ., Lieman, J ., Desai, T., Banks, A., Bray-Ward, P., Ward, D., Hudson, T., Gerety, T., Foote, S., Stein, L., Page, D. C., Lander, E. S., Weissenbach, J., Le Paslier, D., and Cohen, D. (1995). A YAC contig map of the human genome. Nature 377: 175- 183.

Cohen, D., Chumakov, I., and Weissenbach, J . (1993). A first-generation physical map of the human genome. Nature 366: 698-701.

Davies, A. F., Stephens, R. J ., Olavesen, M. G., Heather, L., Dixon, M. J., Magee, A., Flinter, F., and Ragoussis, J . (1995). Evidence of a locus for orofacial clefting on human chromosome $6 \mathrm{p} 24$ and STS content map of the region. Hum. Mol. Genet. 4: 121-128.

Durkin, A. S., Nierman, W. C., Zoghbi, H. Y., J ones, C., Kozak, C. A., and Maglott, D. R. (1994). Chromosome assignment of human brain expressed sequence tags (ESTs) by analysing fluorescently labeled PCR products from hybrid cell panels. Cytogenet. Cell Genet. 65: 86-91.

Farr, C. J ., Easty, D. J ., Ragoussis, J ., Collignon, J ., Lovell-Badge, R., and Goodfellow, P. N. (1993). Characterization and mapping of human SOX4 gene. Mamm. Genome 4: 577- 584.

Foote, S., Voll rath, D., Hilton, A., and Page, D. C. (1992). The human $Y$ chromosome: Overlapping DNA clones spanning the euchromatic region. Science 258: 60-66.

Foulkes, W. D., Ragoussis, J., Stamp, G. W. H., Allan, G. J ., and Trowsdale, J . (1993). Frequent loss of heterozygosity on chromosome 6 in human ovarian carcinoma. Br. J . Cancer 67: 551- 559.

Francke, U. (1994). Digitized and differentially shared human chromosome ideograms for genomic application. Cytogenet. Cell Genet. 65: 206- 219.

Gyapay, G., Morissette, J ., Vignal, A., Dib, C., Fizames, C., Millasseau, P., Marc, S., Bernardi, G., Lathrop, M., and Weissenbach, J . (1994). The 1993- 94 Généthon human genetic linkage map. Nature Genet. 7: 246- 339.

Gyapay, G., Schmitt, K., Fizames, C., J ones, H., Vega-Czarny, N., Spillett, D., Muselet, D., Prud'Homme, J., Dib, C., Auffray, C., Morissette, J., Weissenbach, J ., and Goodfellow, P. N. (1996). A radiation hybrid map of the human genome. Hum. Mol. Genet. 5: 339- 346.

Hayano, T., Sogowa, K., I kihara, Y., Fuji-Quriyama, Y., and Takahashi, K. (1988). Primary structure of human pepsinogen $C$ gene. J. Biol. Chem. 263: 1382-1385.

Heslop-Harrison, J . S., Leitch, A. R., Schwarzacher, T., Smith, J . B., Atkinson, M. D., and Bennett, M. D. (1989). The volumes and morphology of human chromosomes in mitotic reconstructions. Hum. Genet. 84: 27- 34.

Holmquist, G. P. (1992). Chromosome bands, their chromatine flavors, and their functional features. Am. J . Hum. Genet. 51: 1737.

Hudson, T. J ., Stein, L. D., Gerety, S. S., Ma, J ., Castle, A. B., Silva, J ., Slonim, D. K., Baptista, R., Kruglyak, L., Xu, S., Hu, X., Colbert, A. M. E., Rosenberg, C., Reeve-Daly, M. P., Rozen, S., Hui, L., Wu, X., Vestergaard, C., Wilson, K. M., Bae, J . S., Maitra, S., Ganiatsas, S., Evans, C. A., DeAngelis, M. M., Ingalls, K. A., Nahf, R. W., Horton, L. T., J r., Anderson, M. O., Collymore, A. J ., Ye, W., Kouyoumjian, V., Zemsteva, I. S., Tam, J., Devine, R., Courtney, D. F., Renaud, M. T., Nguyen, H., O'Connor, T. J ., Fizames, C., Fauré, S., Gyapay, G., Dib, C., Morissette, J ., Orlin, J . B., Birren, B. W., Goodman, N., Weissenbach, J ., Hawkins, T. L., Foote, S., Page, D. C., and Lander, E. S. (1995). An STS-based map of the human genome. Science 270: 1945- 1954.

J urka, J ., Walichiewicz, J ., and Milosavljevic, A. (1992). Prototypic sequences for human repetitive DNA. J . Mol. Evol. 35: 286- 291.

Nelson, D. L., Ledbetter, S. A., Corbo, L., Maureen, F. W., RamirezSolis, R., Webster, T. D., Ledbetter, D. H., and Caskey, T. (1989) Alu polymerase chain reaction: A method for rapid isolation of human-specific sequences from complex DNA sources. Proc. Natl. Acad. Sci. USA 86: 6686-6690.

Nemani, M., Cherif, D., Chesne, H., Pelandakis, M., Ougen, P., Berger, R., Weissenbach, J., Le Paslier, D., Choen, D., and Cann, H. M. (1994). A YAC contig in $6 p 23$ based on sequence tagged sites. Genomics 22: 388- 396.

Olavesen, M. G., Davies, A. F., Broxholme, S. J., Wixson, J. L., Senger, G., Nizetic, D., Campbell, R. D., and Ragoussis, J. (1995). An integrated map of human chromosome 6p23. Genome Res. 5: 342- 358.

Pappas, G., Polymeropoulos, M. H., Boyle, J. M., and Trent, J . M. (1995). Regional assignment by hybrid mapping of 36 expressed sequence tags (ESTs) on chromosome 6. Genomics 25: 124- 129. 
Peltonen, L. (1995). All out for chromosome six. Nature 378: 665666.

Polymeropoulos, M. H., Xiao, H., Rath, D. S., and Merril, C. R. (1991). Trinucleotide repeat polymorphism at the human Met-tRNA-i gene 1 (TRMI). Nucleic Acids Res. 19: 4306.

Pritchard, M., Fuentes, J. J ., Bosch, A., and Estivill, X. (1994). Towards a transcriptional map of human chromosome 21q22.2-22.3. Third EUROGEM meeting, Montpellier, France. [Abstract.]

Raha-Chowdhury, R., Bowen, D. J ., Stone, C., Pointon, J .J ., Terwilliger, J. D., Shearman, J. D., Robson, K. J. H., Bomford, A., and Worwood, M. (1995). New polymorphic microsatellite markers place the hemochromatosis gene telomeric to D6S105. Hum. Mol. Genet. 4: 1869- 1874.

Ranum, L. P., Chung, M. Y., Duvick, L. A., Zoghbi, H. Y., and Orr, H. T. (1991). Dinucleotide repeat polymorphism at the D6S109 locus. Nucleic Acids Res. 19: 1171.

Sealey, P. G., Whittaker, P. A., and Southern, E. M. (1985). Removal of repeated sequences from hybridization probes. Nucleic Acids Res. 13: 1905- 1922.

Senapathy, P., Shapiro, M. B., and Harris, N. L. (1990). Splice junctions, branchpoint size and exons: Sequence statistics, identification and applications to genome project. Methods Enzymol. 183: 252- 278.

Stone, C., Pointon, J . J ., J azwinska, E. C., Halliday, J . W., Powell, L. W., Robson, K. J . H., Monaco, A. P., and Weatherall, D. J . (1994).
I solation of the CA dinucleotide repeats close to D6S105; linkage disequilibrium with hemocromatosis. Hum. Mol. Genet. 3: 20432046.

Totaro, A., Rommens, J. M., Grifa, A., Lunardi, C., Carella, M., Huizenga, J. J ., Roetto, A., Camachella, C., De Sandre, G., and Gasparini, P. (1996). Hereditary hemochromatosis: Generation of a transcription map within a refined and extended map of the HLA class I region. Genomics 31: 319- 326.

Vernet, C., Boretto, J ., Mattei, M., Takahashi, M., J ack, L. J . W., Mather, I. H., Rouquier, S., and Pontarotti, P. (1993). Evolutionary study of multigenic family mapping close to the human $\mathrm{MHC}$ class I region. J. Mol. Evol. 37: 600-612.

Volz, A., Boyle, J . M., Cann, H. M., Cottingham, R. W., Orr, H. T., and Ziegler, A. (1994). Report of the Second International Workshop on human chromosome 6. Genomics 21: 464-472.

Wapenaar, M. C., Schiaffino, M. V., Bassi, M. T., Scaefer, L., Chinault, A. C., Zoghbi, H. Y., and Ballabio, A. (1994). A YAC based binning strategy facilitating assembly of cosmid contig: 1.6 megabases of overlapping cosmid in Xp22. Hum. Mol. Genet. 3: 11551161.

Weber, J . L., Kwitkok, A. E., May, P. E., and Zoghbi, H. Y. (1992). Dinucleotide repeat polymorphism at the D6S105 locus. Nucleic Acids Res. 19: 968.

Zoghbi, H. Y., and Chinault, A. C. (1995). Generation of YAC contigs. In "YACs: A User Guide" (B. H. Brownstein and D. L. Nelson, Eds.), Freeman, New York. 